\title{
An Epidemiological Study of Habu-bites in the Amami Islands
}

\author{
Ichiro Wakisaka, Mamoru Miyashita, Tetsuo Ando and Atsuko Takano \\ Department of Public Health, Faculty of Medicine, Kagoshima University, Kagoshima
}

\section{INTRODUCTION}

Habu (Trimeresurus flavoviridis) is a venomous snake whose geographical distribution is restricted to certain islands of the Amami and Ryukyu groups. Because of its aggressive nature, habu is greatly feared by those who live in infested areas. Although deaths from habu-bites are relatively rare, local injuries caused by the venom are always serious with extensive necrosis of the tissues.

Many cases of habu-bite have been reported in the infested areas in the past years and several epidemiological studies on these bites have been done ${ }^{1 \sim 5)}$. Few reports have dealt with the population risking habu-bite. We have investigated a possible underlying mechanism of the epidemiological features of habu-bites in the Amami Islands.

\section{MATERIALS}

The materials used were case reports of habu-bites collected from the Amami Islands by local health centers from 1972 to 1976. In the Amami Islands, habu-bites are inevitably reported to local health centers because anti-venom serum is supplied by the government to local communities, free of charge, in exchange for case reports. Thus, these case reports should be a reliable source of statistics. Records show: name, sex, date, time, residence, locality and body-part of the bite. However, information about the place where the habu-bite occurred and the occupation of the victim are either lacking or uncertain. Meteorological data were obtained from the Nase Meteorological Station.

\section{RESULTS AND DisCUSSION}

Over a period of 5 years (from 1972 to 1976) 1285 cases of habu-bite were reported in Tokunoshima and Amamioshima (Amamioshima proper, Yorojima, Kakeromajima, Ukejima and other small islands). Table 1 shows the annual case records of habu-bites by local community units (village, town and city). An average of 257 cases of habu-bite was reported in a year, the highest number being 301 cases in 1973 and the lowest 202 in 1976 . Of the 1285 cases of habu-bite, 923 or $71.8 \%$ occurred on Tokunoshima alone. This indicates that the habu-bite problem is much more serious on Tokunoshima than on Amamioshima. Mori ${ }^{1)}$ reported that the incidence of habu-bite on Tokunoshima was about twice that on Amamioshima. Among the 1285 cases were 11 deaths; a fatality rate of $0.86 \%$. Of these 11 deaths, 2 were caused by a second habu-bite. Thus, the fatality rate for a second habu-bite is about $11 \%$ which is considerably higher than the former rate.

Although the number of deaths from habu-bites was very small, the data suggest that victims who were attacked a second time might have hesitated to receive another injection of anti-venom serum because of the possibility of serum sickness re-occurring. Sasa et al. ${ }^{2)}$ reported that the fatality rate recorded in the Amami Islands was relatively high before 1904 when no anti-venom serum was available and that it declined gradually, probably because 
of the use of anti-venom serum and the general improvement in medical care. No death was reported in 1976.

Table 2 shows the incidence of habu-bites arranged by the localities at which the bites took place and the local community units. The localities are roughly divided into two

Table 1 Annual case records of habu-bites by local community units

\begin{tabular}{c|l|r|r|r|r|r|r}
\hline \multicolumn{1}{c|}{ Year } & 1972 & 1973 & 1974 & 1975 & 1976 & Total \\
\hline \multirow{5}{*}{ Local community } & Kasari-town & 19 & 17 & 16 & 19 & 7 & 78 \\
& Tatsugo-town & 5 & $12(1)$ & 7 & 9 & 15 & $48(1)$ \\
& Nase-city & 16 & 13 & 14 & $14(1)$ & 8 & $65(1)$ \\
& Yamato-village & $12(1)$ & 4 & $4(1)$ & 2 & 2 & $24(2)$ \\
& Sumiyo-village & 6 & 5 & 3 & 4 & 5 & 23 \\
& Setouchi-town & $25(1)$ & 21 & 14 & $25(1)$ & 12 & $97(2)$ \\
& Uken-village & 8 & 6 & 3 & 8 & 2 & 27 \\
& Subtotal & $91(2)$ & $78(1)$ & $61(1)$ & $81(2)$ & 51 & $362(6)$ \\
\hline \multirow{5}{*}{ Tokunoshima } & Tokunoshima-town & $54(1)$ & $81(1)$ & $70(1)$ & 54 & 55 & $314(3)$ \\
& Amagi-town & 36 & 57 & 34 & $54(1)$ & 32 & $213(1)$ \\
& Isen-town & 76 & $85(1)$ & 90 & 81 & 64 & $396(1)$ \\
& Subtotal & $166(1)$ & $223(2)$ & $194(1)$ & $189(1)$ & 151 & $923(5)$ \\
\hline & Total & $257(3)$ & $301(3)$ & $255(2)$ & $270(3)$ & 202 & $1285(11)$ \\
\hline
\end{tabular}

Note: Numbers in parentheses represent the number of deaths

Table 2 Incidence rate of habu-bite arranged by the locality where the bite occurred and by local community units

\begin{tabular}{|c|c|c|c|c|c|c|c|c|c|c|c|c|c|c|}
\hline \multirow{3}{*}{\multicolumn{2}{|c|}{ Local communities }} & \multicolumn{7}{|c|}{$\begin{array}{c}\text { Case records of habu-bites } \\
\text { per } 5 \text { years by types } \\
\text { of locality }\end{array}$} & \multicolumn{2}{|c|}{$\begin{array}{l}\text { Size of the } \\
\text { local } \\
\text { population }\end{array}$} & \multirow{3}{*}{ 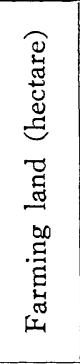 } & \multicolumn{3}{|c|}{$\begin{array}{c}\text { Incidence rate of } \\
\text { habu-bite per unit } \\
\text { per } 5 \text { years }\end{array}$} \\
\hline & & \multicolumn{3}{|c|}{ Outdoor } & \multicolumn{3}{|c|}{ Indoor } & \multirow[b]{2}{*}{ 苞 } & \multirow{2}{*}{ 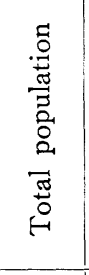 } & \multirow{2}{*}{ 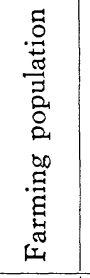 } & & \multirow{2}{*}{ 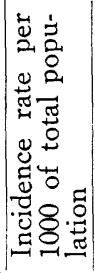 } & \multirow{2}{*}{ 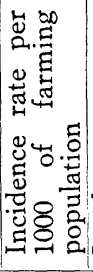 } & \multirow{2}{*}{ 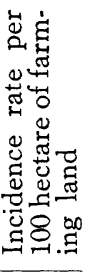 } \\
\hline & & ह్ర్జ & $\frac{\stackrel{0}{5}}{\stackrel{5}{5}}$ & 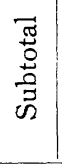 & $\begin{array}{l}q \\
8 \\
0\end{array}$ & $\frac{\stackrel{0}{0}}{\stackrel{5}{5}}$ & 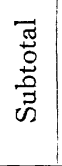 & & & & & & & \\
\hline \multirow{8}{*}{$\begin{array}{l}\text { Amami- } \\
\text { oshima }\end{array}$} & Kasari-town & 32 & 25 & 57 & 9 & 12 & 21 & 78 & 9281 & 3990 & 915 & 8.40 & 19.54 & 8.62 \\
\hline & Tatsugo-town & 13 & 14 & 27 & 10 & 11 & 21 & 48 & 6233 & 2163 & 613 & 7.70 & 22.19 & 7.83 \\
\hline & Nase-city & 8 & 27 & 35 & 19 & 11 & 30 & 65 & 46737 & 2797 & 721 & 1.39 & 23.23 & 9.02 \\
\hline & Yamato-village & 6 & 14 & 20 & 3 & 1 & 4 & 24 & 2634 & 1049 & 357 & 9.11 & 22.87 & 6.72 \\
\hline & Sumiyo-village & 4 & 14 & 18 & 3 & 2 & 5 & 23 & 2468 & 1431 & 216 & 9.31 & 16.07 & 10.64 \\
\hline & Setouchi-town & 22 & 47 & 69 & 19 & 9 & 28 & 97 & 14992 & 4540 & 809 & 6.47 & 7) 21.36 & 11.99 \\
\hline & Uken-village & 5 & 14 & 19 & 4 & 4 & 8 & 27 & 2636 & 1221 & 307 & 10.24 & 22.11 & 8.79 \\
\hline & $\mathrm{S}$ & 90 & 155 & 245 & 67 & 50 & 117 & 362 & 84981 & 17191 & 3938 & 4.26 & 21.06 & 9.19 \\
\hline \multirow{4}{*}{$\begin{array}{l}\text { Tokuno- } \\
\text { shima }\end{array}$} & Tokunoshima-town & 208 & 41 & 249 & 35 & 30 & 65 & 314 & 15374 & 7680 & 2336 & 20.42 & 40.88 & 13.44 \\
\hline & Amagi-town & 106 & 43 & 149 & 36 & 28 & 64 & 213 & 9169 & 7073 & 2152 & 23.23 & 30.11 & 9.89 \\
\hline & Isen-town & 230 & 54 & 284 & 74 & 38 & 112 & 396 & 11053 & 8259 & 2187 & 35.83 & 47.95 & 18.10 \\
\hline & Subtotal & 544 & 138 & 682 & 145 & 96 & 241 & 923 & 35596 & 23012 & 6675 & 25.93 & 40.11 & 13.82 \\
\hline \multicolumn{2}{|r|}{ Total } & 634 & 293 & 927 & 112 & 246 & 354 & 1285 & 120577 & 40203 & 10613 & 10.65 & 31.96 & 12.11 \\
\hline
\end{tabular}


categories; indoors and outdoors. The former comprises rooms, beds, lavatories, kitchens and animal sheds or gardens and the latter farms, rice-fields, forests, tombs, roads or passes, swamps, seashores and river banks. Of the 1285 cases of habu-bite, 927 or $72.1 \%$ occurred outdoors. Those bites which took place on farms were 634 or $49.3 \%$ of the total. The incidence rate of habu-bites per thousand of the local population differs remarkably among the community units; the lowest 1.39 is for Nase city and the highest 35.83 is for Isen town. However, the incidence rate of habu-bites per thousand of the local farming population and per 100 hectares of farm land did not differ so widely among the community units. The lowest, 16.07, was in Sumiyo village and the highest, 47.95, was in Isen town for population, and the lowest, 6.72, was in Yamato village and the highest, 18.10, was in Isen town for land units. This indicates that the incidence of habu-bite is closely related to farming.

We have assumed here, that all members of a given population- "the population risking habu-bite"-are equally exposed to the risk. If habu-bite is unusual and occurs at random among a population risking habu-bite, we can expect a complete Poisson distribution of the frequency of habu-bites per head. The total number of victims in the 1285 cases of habu-bite was 1265, of which 1246 were attacked only once, 18 twice and 1 three times as shown in Column 1 of Table 3. Thus, we have information only on those who had at least one bite. Therefore, the distribution for the frequency of habu-bites per head must be a truncated Poisson as follows;

$$
P(x)=\frac{m^{x}}{\left(e^{m}-1\right) x !} \quad x=1,2,3, \cdots
$$

where $m$ is the incidence rate of habu-bite and $x$ is the frequency of habu-bites per head. The size of the total and farming populations combined for Tokunoshima and Amamioshima was 120577 and 40203 , respectively, from the census of 1975 . If the total cases of habu-bite are randomly derived from the total population, then the frequency distribution of habu-bite containing the class 0 can be shown as Column 2 of the table. The fitted values for the Poisson series were calculated in the usual way as shown in Column 3 of the table. Clearly the fit is unsatisfactory, and this is borne out by the high value of $\chi^{2}, 22.615$, on one degree of freedom, for which $\mathrm{P}<0.005$. However, when we turn to the analysis of the data based on the farming population, the frequency distribution of habu-bite containing the class 0 can be shown as Column 5 of the table The fitted values for the Poisson series indicate good agree-

Table 3 Frequency distributions of habu-bites per head during a 5 year period: their fitness to the Poisson distribution

\begin{tabular}{|c|c|c|c|c|c|c|c|c|}
\hline & & \multirow{3}{*}{$\begin{array}{c}\text { Number of } \\
\text { victims } \\
\text { among the } \\
\text { population } \\
\text { risking } \\
\text { hubu-bite }\end{array}$} & \multicolumn{3}{|c|}{ Total population } & \multicolumn{3}{|c|}{ Farming population } \\
\hline & & & \multicolumn{2}{|c|}{$\begin{array}{l}\text { Number of victims } \\
\text { attacked by habu }\end{array}$} & \multirow{2}{*}{$\begin{array}{l}\text { Devia- } \\
\text { tion }\end{array}$} & \multicolumn{2}{|c|}{$\begin{array}{l}\text { Number of victims } \\
\text { attacked by habu }\end{array}$} & \multirow{2}{*}{$\begin{array}{l}\text { Devia- } \\
\text { tion }\end{array}$} \\
\hline & & & Observed & Estimated & & $\begin{array}{c}\text { Observ- } \\
\text { ed }\end{array}$ & Estimated & \\
\hline \multicolumn{2}{|c|}{ Column number } & (1) & (2) & (3) & (4) & (5) & (6) & (7) \\
\hline \multirow{5}{*}{$\begin{array}{l}\text { Frequency of } \\
\text { habu-bites per } \\
\text { head over } 5 \\
\text { year period }\end{array}$} & 0 & & 119312 & 119298.833 & 13.167 & 38938 & 38938.4276 & 0.4276 \\
\hline & 1 & 1246 & 1246 & 1271.367 & 25.367 & 1246 & 1244.4721 & 1.5279 \\
\hline & 2 & 18 & 18) & $6.774)$ & & 18) & 19. 8866) & \\
\hline & 3 & 1 & $1\} 19$ & $0.024\} 6.768$ & 12.232 & $1\} 19$ & 0.211820 .1001 & 1. 1001 \\
\hline & 4 & 0 & 0 & $0.000)$ & & 0) & 0.0017 & \\
\hline \multicolumn{2}{|c|}{ Population size } & 41993 & 120577 & 120576.998 & & 40203 & 40202.9998 & \\
\hline \multicolumn{2}{|l|}{ Parameter } & 0.0306 & 0.010657 & \multicolumn{2}{|c|}{$\chi^{2}=22.615$ D. $f=1$} & \multicolumn{3}{|c|}{$\chi^{2}=0.062$ D.f $=1$} \\
\hline
\end{tabular}


ment and the well-fitting $\chi^{2}$ is 0.062 on one degree of freedom, which is unexceptionable. Therefore, we assume that the total cases of habu-bite randomly occurred among a population of some 40000 , "the population risking habu-bite", rather than the total population. The objective reality for the population risking habu-bite is unknown at present but it may be related to farming. Although we had no information on those who were not attacked by habu, the incidence rate of habu-bite for the risk-population could be readily estimated by the maximum likelihood method as the unknown parameter $m$ of the equation given above ${ }^{6)}$. Thus, a value of 0.0306 was obtained, see Column 1 of the table. Accordingly, the size of the population risking habu-bite is $1285 \div 0.0306=41993.464$. This is approximately $35 \%$ of the total population and is roughly equal to the size of the farming population. This appears to be strong proof that the majority of the risk-population belongs to the farming group. The rest of the population may be free from the danger of habu-bite.

Table 4 Incidence of habu-bite arranged by localities and body parts

\begin{tabular}{|c|c|c|c|c|c|}
\hline Locality & Upper extremity & Lower extremity & Head & Trunk & Total \\
\hline Outdoor & $467(50.4)$ & $440(47.5)$ & $14(1.5)$ & $6(0.6)$ & $927(100)$ \\
\hline Indoor & $139(38.8)$ & $179(50.0)$ & $16(4.5)$ & $24(6.7)$ & $358(100)$ \\
\hline Total & $606(47.2)$ & $619(48.2)$ & $30(2.3)$ & $30(2.3)$ & $1285(100)$ \\
\hline
\end{tabular}

Note: Numbers in parentheses represents percents of total cases

Table 4 shows the incidence of habu-bite arranged by localities and the body-parts of the bites. The body-parts most frequently attacked by habu are the upper and lower extremities. In the case of outdoor habu-bites, $98 \%$ of the total occurred on the upper and lower extremities. This suggests that almost all the habu-bites may be preventable if these body-parts are effectively protected by long leather boots or heavy gloves. In the case of indoor habu-bite, however, about $11 \%$ of the total cases occurred on other body-parts such as the head and trunk. In these cases, the prognosis may be serious because the venom spreads towards the proximal parts of the body. Sasa et al. ${ }^{2)}$ have indicated that a higher fatality rate was recorded for habu-bites on the trunk than for bites on the upper and lower extremities.

Fig. 1 shows the diurnal distribution of habu-bite by types of locality. The time of the habu-bite was arranged in 4 hour intervals. Outdoor habu-bites mainly occurred in the day-time with the highest incidence between 8 a.m. and 12 a.m. Indoor bites mainly took place at night with the highest incidence between 8 p.m. and 12 p.m. The habu is nocturnal while humans are mainly diurnal. Therefore, the diurnal pattern for habu-bites suggests that the outdoor bite is mainly a result of the activities of humans and indoor bites are a result of activities of habu.

Table 5 shows the annual case records for habu-bites by months. The table shows the incidence of habu-bites differs greatly ac-

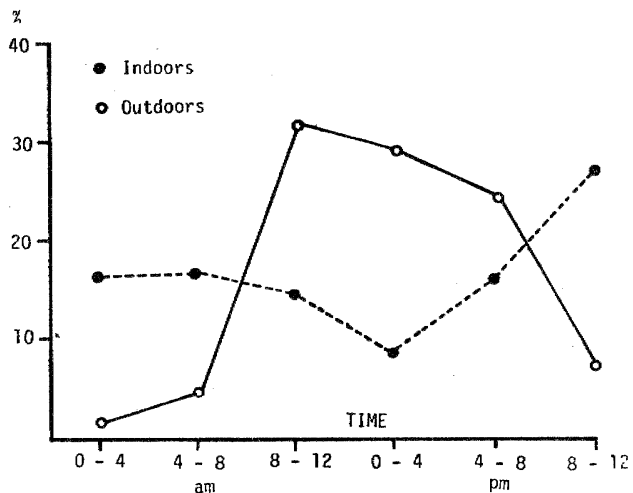

Fig. 1 Diurnal distribution of habu-bites by types (indoor and outdoor) of locality cording to the month. There is a peak in June, followed by a lesser one in May and July. The lowest incidence is in December. Tanaka ${ }^{\text {r) }}$ has reported that in the Amami 
Islands, the number of habu captured and taken to health centers was highest in June. In fact, of the 1285 cases of habu-bite, 584 or $45 \%$ occurred during three months, from May to July. The seasonal variation in habu-bite may be attributed to meteorological conditions, e.g. atmospheric temperature, humidity and precipitation on the activities of both humans and habu. Sasa et al. ${ }^{3)}$ reported in a previous paper that in the Amami Islands, the highest incidence of habu-bite was observed not in August-the hottest season-but in June which has the highest amount of precipitation.

Table 6 shows the distribution of the frequency of habu-bites per day. An average of 0.703338 cases of habu-bite occurred within a day, but the highest number was 7 cases. Fitted values for the Poisson distribution are given in Column 3 and for the negative binomial

Table 5 Annual case records of habu-bite by months

\begin{tabular}{|c|c|c|c|c|c|c|}
\hline Month Year & 1972 & 1973 & 1974 & 1975 & 1976 & Total (\%) \\
\hline January & 6 & 4 & 3 & 3 & 2 & $18(1.4)$ \\
\hline February & 7 & 14 & 12 & 8 & 14 & $55(4.3)$ \\
\hline March & 15 & 25 & 16 & 9 & 21 & $86(6.7)$ \\
\hline April & 23 & 26 & 24 & 18 & 20 & $111(8.6)$ \\
\hline May & 32 & 53 & 26 & 37 & 30 & $178(13.9)$ \\
\hline June & 57 & 46 & 54 & 50 & 44 & 251 (19.5) \\
\hline July & 33 & 32 & 24 & 37 & 29 & $155(12.1)$ \\
\hline August & 25 & 24 & 20 & 40 & 9 & $118(9.2)$ \\
\hline September & 22 & 38 & 29 & 27 & 17 & $133(10.4)$ \\
\hline October & 17 & 27 & 37 & 27 & 9 & $117(9.1)$ \\
\hline November & 12 & 9 & 9 & 11 & 5 & $46(3.6)$ \\
\hline December & 8 & 3 & 1 & 3 & 2 & $17(1.3)$ \\
\hline Total & 257 & 301 & 255 & 270 & 202 & $1285(100.0)$ \\
\hline
\end{tabular}

Table 6 Frequency distributions of habu-bites per day: their fitness to the Poisson distribution and to the negative binomial distribution

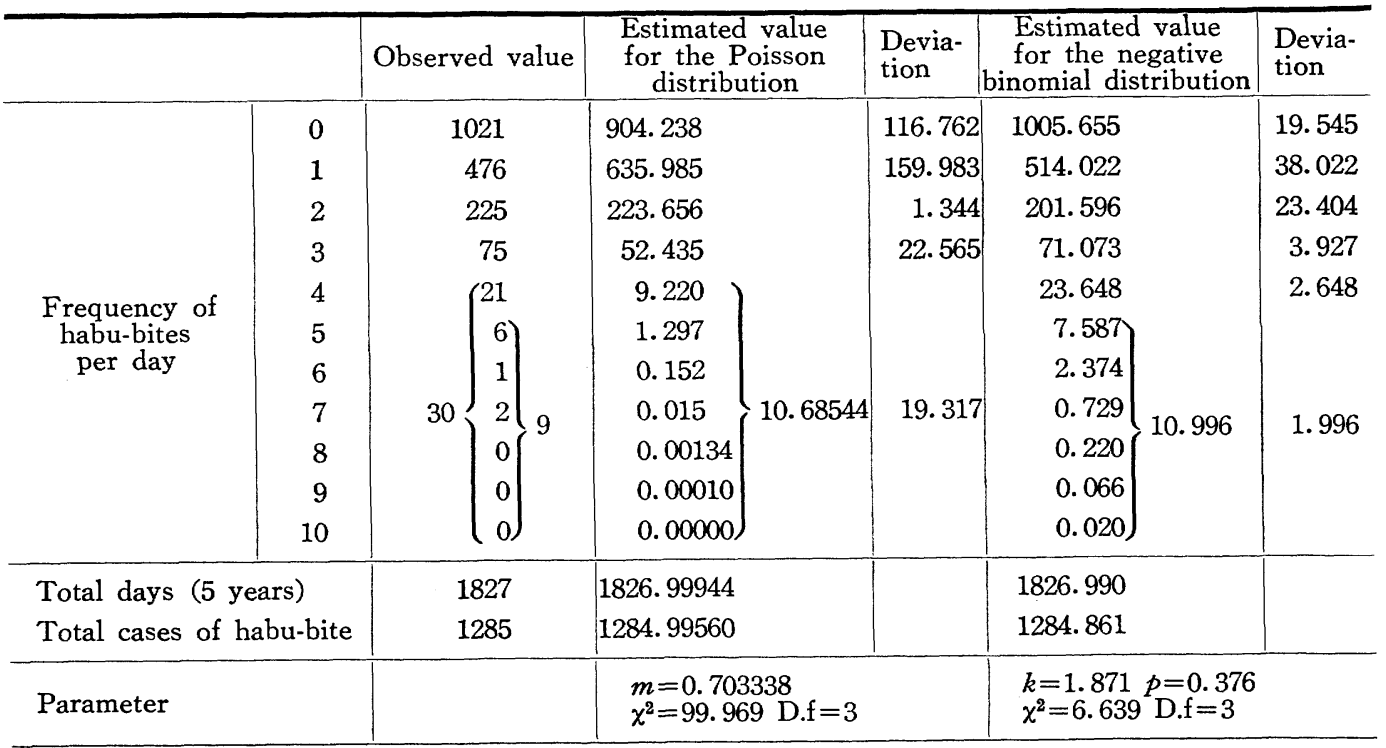




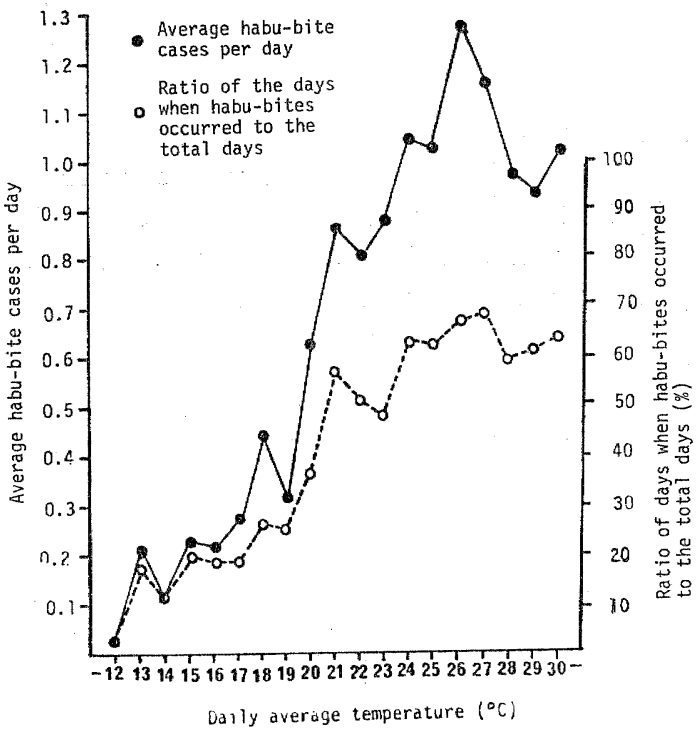

Fig. 2 Relationship between the incidence of habu-bites per day and the daily average temperature

distribution in Column 5. ${ }^{6}$ The fit to the Poisson series is inadequate. In fact $\chi^{2}$ is 99.969 on 3 degrees of freedom, which is significant at the $0.1 \%$ level. In contrast, the fitted values for the negative binomial distribution indicate good agreement and the goodness-of-fit for $\chi^{2}$ is 6.639 on 3 degrees of freedom, which is unexceptionable. This suggests that the days when habu-bites occur tend to cluster.

Figures 2, 3 and 4 show the relationships between the incidence of habu-bites per day and meteorological conditions. Fig. 2 shows that the incidence of habu-bite increased with a rise in temperature and reached a peak at $26^{\circ} \mathrm{C}$ after which it tended to decrease. This indicates that the optimum temperature for habu activity is about $26^{\circ} \mathrm{C}$. The incidence of habu-bite also increased steadily with an increase in humidity. Precipitation is also related to the incidence of habu-bite. As Fig. 4 shows, a high incidence of habu-bite was observed when the amount of precipitation (on the day of the bite or on the preceding day) exceeded $10 \mathrm{~mm}$.

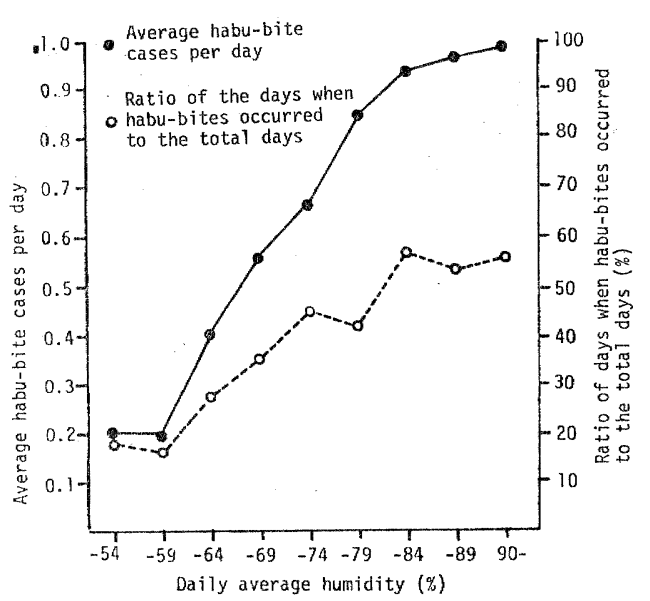

Fig. 3 Relationship between the incidence of habu-bites per day and the daily average humidity

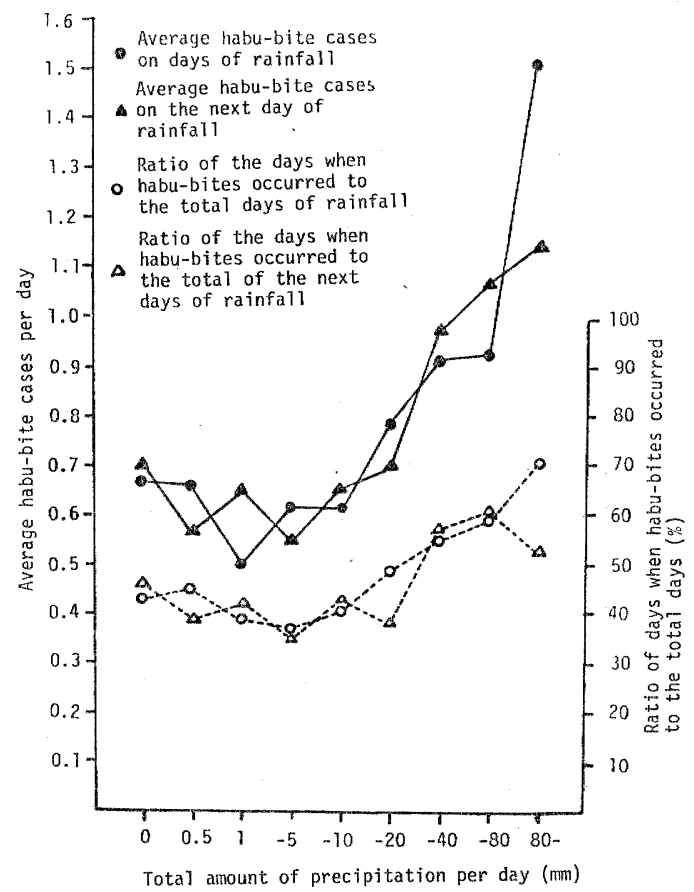

Fig. 4 Relationship between the incidence of habu-bites per day and the amount of precipitation per day These facts suggest the most probable explanation for the highest incidence of habu-bite being in June. 
We concluded that: The habu-bite in the Amami Islands is an unusual event; The size of the hypothetical population risking habu-bite is approximately $35 \%$ of the total population and is roughly equal to the size of the farming population; The rest of the population should be free from the danger of habu-bite; and the body-parts most frequently bitten are the upper and lower extremities. Therefore, most habu-bites appear to be preventable by wearing leather boots or heavy gloves. This is acceptable in theory but not always practicable in daily life. Thus, environmental improvements such as the paving of roads and agrarian reforms, may be useful in reducing the opportunities for humans to encounter habu.

\section{SUMMARY}

Epidemiological features of habu-bite in the Amami Islands were investigated. Over a period of 5 years (1972 to 1976) 1285 cases of habu-bite, including 11 deaths, were recorded on Tokunoshima and Amamioshima. The total number of victims was 1265, of which 1246 were attacked once, 18 twice and 1 three times during the 5 year period. Assuming that the frequency of habu-bite per head is a truncated Poisson distribution, the size of the hypothetical population risking habu-bite was estimated by the maximum likelihood method. We obtained the value of 41993 , which was approximately $35 \%$ of the total population and roughly equal to the size of the farming population. The incidence rate of habu-bite per unit of local population differed greatly according to the community unit (village, town or city), but the rates for the farming population and farming land did not differ greatly among the local communities. Patterns for the seasonal and diurnal distribution of habu-bite clearly indicated that the incidence of bites reflects the activities of both humans and habu.

\section{REFERENCES}

1) Mori, T. : Studies on the Habu (Trimeresurus flavoviridis) and Habu-bite in Amami-Oshima (Tr-2), Epidemiological Studies on the poisonous snake-bite by the habu. Kagoshimadaigaku Igakuzasshi, 13, 96-114 (1961) in Jap.

2) Sasa, M., Teruya, K., Uchiyama, H. and Iwai, S. : Epidemiology of the poisonous snake in the Amami and Ryukyu Islands. Jap. J. Exp. Med. 29, 417-444 (1959).

3) Sasa, M., Tanaka, H., Sako, K. and Mori, T. : Epidemiology of the bite-cases of the poisonous snake in the Amami Islands. Nisshin Igaku, 43, 489-497 (1957) in Jap.

4) Sawai, Y. : Problem of the poisonous snake, habu, in Amami-Oshima. Tokyo Ijishinshi, 74, 641-642 (1957) in Jap.

5) Uchiyama, H. : Studies on habu, Part I. Epidemiological studies on snake bite by the habu in Amami-Oshima. Kagoshimadaigaku Igakuzasshi, 10, 303-317 (1958) in Jap.

6) Itoh, Y.: Guide book of Animal-ecology (Dobutsuseitaigakunyumon-Kotaigunseitaigakuhen), 3rd ed. Kokinshoin, pp. 64-91 (1962) in Jap.

7) Tanaka, H. : Activity and Behavior of the Habu, Trimeresurus flavoviridis. The Snake, 5, 116-132 (1973). 


\title{
奄美諸島における“はぶ”咬傷の疫学的研究
}

\author{
脇阪一郎, 宮下 衞, 安 藤哲夫, 高野敦子 \\ 鹿児島大学医学部公策衛生学教室
}

奄美諸島における “はふ”咬傷の疫学像についての調査を行った。1972年から1976年の 5 年間に, 徳之島, 奄 美大島両島で, 死亡11例を含む 1285 件の “はふ”咬傷が記録されている。犠牲者の総数は, 5 年間を通して 1265 人で, そのうち, 1246 人は 1 回だけの咬傷をうけており, 18 人は 2 回, 1 人は 3 回の咬傷をうけていた。1人あ たりの “はふ”咬傷回数の頻度分布は, “切れたポアソン分布”であるという仮定の下に, 最无法によって, “は

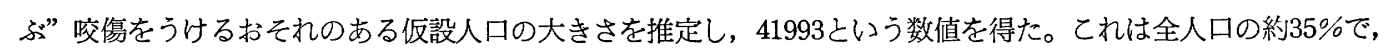
農業人口のサイズにほぼ匹敵するものであった。単位地域人口あたりの “はぶ”咬傷率は, 地域（村, 町, 市) により大きなちがいがみられたが, 単位農業人口あたり或いは単位農地面積あたりの“はぶ”咬傷率には, 地域 間でそれほどちがいはなかった。“はふ”咬傷の季節的変動及び 1 日の時間変動のパターンは, “はぶ”咬傷の発 生は, 人と “はぶ”の双方の活動によって生じたものであるてとを明瞭に示していた。

（受付 1978年2月27日） 